International Journal of Advanced Biological and Biomedical Research Available online at http:www.ijabbr.com

Volume 8, Issue 2 (2020) pp. 180-192

DOI: 10.33945/SAMI/IJABBR.2020.2.8

Original Article

\title{
Effects of Emamectin Benzoate Combined with Acetamiprid, Eforia and Hexaflumuron Against Tuta Absoluta (Lep.: Gelechiidae)
}

\section{Mohsen Taleh ${ }^{1}$, Hooshang Rafiee Dastjerdi*,1, Bahram Naseri ${ }^{1}$, Aziz Sheikhi Garjan², Khalil Talebi Jahromi ${ }^{3}$}

\author{
${ }^{1}$ Departmant of Plant Protection, Faculty of Agriculture and Natural resources, University of \\ Mohaghegh Ardabili, Ardabil, Iran \\ ${ }^{2}$ Iranian Research Institute of Plant Protection,Tehran, Iran \\ ${ }^{3}$ Department of Plant Protection, University of Tehran, Karaj, Iran \\ *Corresponding Author E-mail: Hooshangrafiee@gmail.com
}

Received: 2 September 2019, Revised: 05 November 2019, Accepted: 10 November 2019

\begin{abstract}
Tomato leafminer, Tuta absoluta Meyrick (Lepidoptera: Gelechiidae) is one of the most destructive pests of tomato in many parts of the world including Iran. The toxicity of emamectin benzoate alone and combined with acetamiprid, eforia (thiamethoxam +lambda-cyhalotrin) and hexaflumuron were evaluated against $2^{\text {nd }}$ instar larvae of Tuta absoluta (Meyrick) under $25 \pm 1{ }^{\circ} \mathrm{C}$, the relative humidity of $75 \pm 5 \%$ and a photoperiod of 16:8 (L:D). Also, the mixtures of tested insecticides with emamectin benzoate at $\mathrm{LC}_{15}: \mathrm{LC}_{15}$ ratio were evaluated on the activity of general esterase enzyme and total protein content of $2^{\text {nd }}$ instar larvae. After 96 hours, emamectin benzoate had the highest toxicity $\left(\mathrm{LC}_{50}=0.52\right.$ mg A.I./L), followed by acetamiprid ( $\mathrm{LC}_{50}=56.39 \mathrm{mg}$ A.I. $\left./ \mathrm{L}\right)$ and eforia $\left(\mathrm{LC}_{50}=312.01 \mathrm{mg}\right.$ A.I./L). Hexaflumuron showed no toxicity against larvae. The combination of emamectin benzoate with acetamiprid at $\mathrm{LC}_{50}: \mathrm{LC}_{50}$ ratioproduced synergistic effects and all of the other ratios showed additive effects. The emamectin benzoate combined with either eforia or hexaflumuron at all of the ratios produced additive and antagonistic effects, respectively. Esterase activity of larvae increased when emamectin benzoate was mixed with either acetamiprid or eforia, but no significant differences were seen between emamectin benzoate alone and its mixture with hexaflumuron. The combination of emamectin benzoate with tested insecticides significantly reduced the total protein content of larvae. According to the results of this study, the mixtures of acetamiprid and eforia with emamectin benzoate showed higher negative impacts against $2^{\text {nd }}$ instar larvae than emamectin benzoate alone.
\end{abstract}

Key words: Mixture, Esterase, Total protein, Emamectin benzoate, Tuta absoluta 


\section{Introduction}

Tuta absoluta Meyrick (Lepidoptera: Gelechiidae) is a native micro lepidopteran pest of South America which can affect all aerial parts of the host plants (leaves, flowers, stems and fruit). This pest has a high potential to cause up to $100 \%$ economic losses (Torres et al., 2001; EPPO 2005; Desneux et al., 2010).

Chemical control of the leafminers such as T. absolutais is difficult due to its hidden behavior inside the leaf, high reproductive capacity, polyvoltine nature and poor spraying technology, so it is necessary to apply various insecticides several times in a season to control the pest (Braham and Hajji, 2011). However, T. absoluta has a great potential to develop resistance to conventional insecticides such as organophosphates (OPs), pyrethroids and avermectins (Siqueira et al., 2000; Siqueira et al., 2001; Roditakis et al., 2013). Higher levels of T. absoluta resistance to abamectin, Cartap and permethrin (Siqueira et al., 2000) and spinosad (Campos et al., 2014) are related to the extreme application of these insecticides by farmers.

Using the mixtures of pesticides is one of the effective ways to postpone the development of insecticide resistance or to struggle current resistance in a pest species. This method is generally used, in the field, to increase the spectrum of control when multiple pests are aggressive simultaneously or against a single pest (Ishaaya et al., 1985). The combination of insecticides with various modes of action could either be synergistic, additive or antagonistic against an insect species. If the mixtures would be synergistic, the costs of excessive use of insecticides might effectively be reduced (Wolfenbarger and Cantu, 1975).

Insecticides could influence the activity of metabolic enzymes such as glutathione Stransferases (GSTs), esterase, mixed function oxidase (MFO) as well as total protein content. General esterases and GSTs have an important role in detoxifying synthetic and non-synthetic insecticides (Vanhaelen et al., 2001). Research demonstrated that the combination of two different insecticides might result in inhibition of the detoxification enzymes in many pests and hence can lead to effective control of them (Martin et al., 2003). Several researchers reported that OPscombined with pyrethroids had synergistic effect against several pests (All et al., 1977; Asher et al., 1986). For example, combination of chlorpyrifos with either emamectin benzoate, indoxacarbor spinosad showed a synergism against Phenacoccus solenopsis Tinsley (Hemiptera: Pseudococcidae) (Saddiq et al., 2017). The mixtures of emamectin benzoate with deltamethrin significantly increased toxicity against Musca domestica L. (Diptera: Muscidae) Also, emamectin benzoate mixed with bifenthrin showed an antagonistic effect against this housefly (Khan et al., 2013). Findings of (Ghoneim et al., 2012) indicated that chlorpyrifos produced high synergism when mixed with hexaflumuron and triflumuron and produced an additive effect when mixed with chlorfluazuron, chromafenozide and tobufenozite on Spodopteralittoralis (Boisd.) (Lepidoptera: Noctuidae).

Emamectin benzoate is a new insecticide isolated from the avermectin family of natural products. These products have been used for the control of Lepidoptera pests on vegetable crops worldwide, with a special efficacy against T. absoluta (Gacemi and Guenaoui, 2012)

The present study was done to find out the toxicity of mixtures of emamectin benzoate with either acetamiprid, eforia or hexaflumuron against T. absoluta larvae as well as their effects on the biochemical traits such as general detoxifying esterases and total protein content in the pest. It is hypothesized that the mixtures of tested insecticides could delay the 
development of insecticide resistance and reduce the costs and risks of extreme use of them.

\section{Experimental}

\section{Insects}

The specimens of T. absoluta were collected from tomato farms located in Moghan region, Ardabil, Iran. The insects were maintained in the growth chamber on the commercial tomato (Solanum lycopersicon L. var. Super Strain B) under controlled conditions at $25 \pm 1 \mathrm{C}^{\circ}$, the relative humidity of $75 \pm 5 \%$ and a photoperiod of 16:8 (L:D).

\section{Insecticides}

Commercial formulations of the following insecticides were used: emamectin benzoate (Proclaim ${ }^{\circledR}$ 5\% SG; Syngenta, Switzerland), acetamiprid (Mospilan 20\% WP; Ariashimi, Iran), eforia (thiamethoxam+lambda-cyhalotrin) (Eforia 240\% OD; Syngenta, Switzerland), hexaflumuron (Consalt 10\% EC; Ariashimi, Iran)

\section{Bioassays}

The toxicity of tested insecticides was assessed against $2^{\text {nd }}$ instar larvae of T. absoluta using the tomato leaves. The tomato leaves were dipped into five different concentrations of each insecticide for $15 \mathrm{~s}$ and left to be dried for $1 \mathrm{~h}$ under room temperature. Twenty $2^{\text {nd }}$ instar larvae of T. absoluta were transferred on treated leaves located in a $10 \mathrm{~cm}$ diameter Petri dish. Tween-80 was added to the concentrations as a surfactant at a concentration of $0.05 \%(\mathrm{v} / \mathrm{v})$. Leaves dipped in distilled water+Tween-80 as control. The mortality of larvae was recorded at time intervals of $24,48,72$ and $96 \mathrm{~h}$ after treatments. The experiments were done in triplicates for each insecticide concentration, and each bioassay was repeated three times (Galdino et al., 2011).

\section{Combinations}

Newly molted $2^{\text {nd }}$ instar of T.absoluta was exposed to binary mixtures of emamectin benzoate with acetamipridor eforia at $\mathrm{LC}_{10}, \mathrm{LC}_{15}, \mathrm{LC}_{25}$ and $\mathrm{LC}_{50}$, and hexaflumuron at $100 \mathrm{mg} / \mathrm{L}^{-1} \mathrm{using}$ the leaf-dip method. Twenty larvae were released in each Petri dish. Leaves dipped in distilled water were used as control. Mortality was scored at time intervals of 24, 48, 72 and $96 \mathrm{~h}$ after treatments. The experiments were conducted in triplicates for each insecticide concentration, and each bioassay was repeated three times (Galdino et al., 2011; Abbas, 2015).

\section{Determination of general esterase activity}

General esterase activity of $2^{\text {nd }}$ instar larvae treated with emamectin benzoate combined with either acetamiprid or eforia at $\mathrm{LC}_{15}: \mathrm{LC}_{15}$ ratio, and hexaflumuron at $\mathrm{LC}_{15}: 100 \mathrm{mg} \mathrm{L}^{-1}$ ratio, was assayed according to the method of van Asperen (1962). $\alpha$-Naphthyl acetate $(\alpha$-NA) and $\beta$ naphthyl acetate $(\beta$-NA) were used as substrates for $\alpha$-esterase and $\beta$-esterase activity, respectively. Fifteen $2^{\text {nd }}$ instar larvae were homogenized in $70 \mu \mathrm{l}$ of $40 \mathrm{mM}$ phosphate buffer (pH 7.0) on ice. They were then centrifuged at 10,000 g at $4^{\circ} \mathrm{C}$ for $20 \mathrm{~min}$. The quantity of $90 \mu \mathrm{l}$ of the substrate was added to the microplate, thenpreincubated at $30{ }^{\circ} \mathrm{C}$ for $10 \mathrm{~min}$. The amount of $90 \mu \mathrm{l}$ of Fast Blue RR salt was added to the microplate, then the naphthol production 
was monitored by measuring absorbance at 450 and $540 \mathrm{~nm}$ for $\alpha$-NA and $\beta$-NA, respectively, using microplate reader (Anthos 2020, Austria). All experiments were replicated three times.

\section{Determination of total protein content}

The effect of mixtures of emamectin benzoate with either acetamiprid or eforia at $\mathrm{LC}_{15}: \mathrm{LC}_{15}$ ratio and hexaflumuron at $\mathrm{LC}_{15}: 100 \mathrm{mg} \mathrm{L}^{-1}$ ratio, on the total protein content of $2^{\text {nd }}$ instar larvae was determined according to Bradford (1976), using bovine serum albumin (Bio-Rad) (Sigma) as a standard protein. The measurement was performed using a microplate reader at $595 \mathrm{~nm}$. All experiments were replicated three times.

\section{Data analysis}

The data were analyzed using PROBIT in order to determine lethal concentrations $\left(\mathrm{LC}_{30}, \mathrm{LC}_{50}\right.$, and $\mathrm{LC}_{90}$ ). The mean mortality of $2^{\text {nd }}$ instar larvae treated with different concentrations of each insecticide, after checking for normality, was analyzed by one-way analysis of variance (ANOVA) at a 5\% level of significance by LSD test.Abbott's formula (Abbott 1925) was used for correcting mortality data.

The expected mortality $\left(\mathrm{M}_{\mathrm{E}}\right)$ for the combination of emamectin benzoate with different insecticides was accounted through formula $M_{E}=M_{B}+M_{A}\left(1-M_{B}\right), M_{B}$ signifying observed mortality caused by different insecticides; $M_{A}$ signifying observed mortality caused by emamectin benzoate. Results from a chi-square test, $\chi^{2}=\left(M_{A B}-M_{E}\right)^{2} / M_{E}$, where $M_{A B}$ is the observed mortality for the combination of emamectin benzoate with different insecticides, were compared to the chi-square table value. If the calculated chi-square was overstepped the table value $(\mathrm{df}=1)$, it would be a nonadditive effect. The difference $\mathrm{M}_{\mathrm{AB}}-\mathrm{M}_{\mathrm{E}}>0$ indicated synergism; and the difference $\mathrm{M}_{A B}-\mathrm{M}_{\mathrm{E}}<0$ indicated antagonism (Koppenhofer and Kaya, 1996).

General esterase activity and total protein content data were subjected to ANOVA. Means were compared by LSD test and significant differences were recorded with SPSS software ver. 16 at $\mathrm{P}=0.05$.

\section{Results and discussion}

\section{LCvalues}

Toxicity values for all insecticide treatments on $2^{\text {nd }}$ instar larvae of T. absoluta are shown in Table 1. The data demonstrated that emamectin benzoate showed the highest toxicity $\left(\mathrm{LC}_{50}=0.52 \mathrm{mg}\right.$ A.I. $\left./ \mathrm{L}\right)$, followed by acetamiprid $\left(\mathrm{LC}_{50}=56.39 \mathrm{mg}\right.$ A.I. $\left./ \mathrm{L}\right)$ and eforia $\left(\mathrm{LC}_{50}=312.01\right.$ mg A.I./L). Hexaflumuron had no toxicity against T. absoluta.

Table 1. Toxicity of three tested insecticides against $2^{\text {nd }}$ instar larvae of Tuta absoluta under laboratory conditions

\begin{tabular}{cccccccc}
\hline Insecticide & $\begin{array}{c}\mathbf{L C}_{10}(\mathbf{m g} \\
\mathbf{A I} / \mathbf{L})\end{array}$ & $\begin{array}{c}\mathbf{L C}_{15}(\mathbf{m g} \\
\mathbf{A I} / \mathbf{L})\end{array}$ & $\begin{array}{c}\mathbf{L C}_{25}(\mathbf{m g} \\
\mathbf{A I} / \mathbf{L})\end{array}$ & $\begin{array}{c}\mathbf{L C}_{50}(\mathbf{m g} \mathbf{A I} \\
/ \mathbf{L})\end{array}$ & $\begin{array}{c}\text { Slope } \\
\mathbf{\pm S E}\end{array}$ & $\chi^{2}$ & $\begin{array}{c}\text { Toxicity* } \\
\text { index at } \\
\mathbf{L} \mathbf{C}_{50}\end{array}$ \\
\hline $\begin{array}{c}\text { Emamectin } \\
\text { benzoate }\end{array}$ & 0.14 & 0.18 & 0.26 & 0.52 & $2.3 \pm .27$ & 3.63 & 100 \\
$\begin{array}{c}\text { Acetamiprid } \\
\text { Eforia }\end{array}$ & 18.07 & 22.47 & 30.98 & 56.39 & $2.5 \pm .28$ & 2.08 & 0.92 \\
\hline
\end{tabular}

$* \mathrm{LC}_{50}$ of the efficient compound/LC ${ }_{50}$ of the other compound $\times 100$ (Sun, 1950) 


\section{Combinations}

Binary mixtures of emamectin benzoate with acetamiprid, eforia and hexaflumuron at different concentrations showed additive, synergistic and antagonistic interactions (Table 2 ). The mixtures of emamectin benzoate with acetamiprid at $\mathrm{LC}_{10}: \mathrm{LC}_{10}, \mathrm{LC}_{15}: \mathrm{LC}_{15}$ and $\mathrm{LC}_{25}: \mathrm{LC}_{25}$ ratios showed additive effects. The emamectin benzoate mixed with acetamiprid at $\mathrm{LC}_{50}: \mathrm{LC}_{50}$ ratio showed synergistic interaction and its mixtures with eforia at $\mathrm{LC}_{10}: \mathrm{LC}_{10}$, $\mathrm{LC}_{15}: \mathrm{LC}_{15}, \mathrm{LC}_{25}: \mathrm{LC}_{25}$ and $\mathrm{LC}_{50}: \mathrm{LC}_{50}$ showed additive effects. The combination of hexaflumuron with emamectin benzoate showed an antagonism interaction.

Table 2. Combination of emamectin benzoate with several insecticides on $2^{\text {nd }}$ instar larvae of Tuta absoluta under laboratory conditions

\begin{tabular}{|c|c|c|c|c|c|c|c|}
\hline Combination & Ratio & $\begin{array}{c}\text { Observed } \\
\text { mortality } \\
(\%)\end{array}$ & $\begin{array}{c}\text { ME } \\
(\%)^{a}\end{array}$ & $\mathrm{X}^{2}$ & $\mathbf{P}$ & $\mathbf{N b}^{\mathbf{b}}$ & Interactionc \\
\hline $\begin{array}{c}\text { Emamectin } \\
\text { benzoate+Acetamiprid }\end{array}$ & $\mathrm{LC}_{10}+\mathrm{LC}_{10}$ & 27 & 20.8 & 1.84 & 0.05 & 180 & additive \\
\hline $\begin{array}{c}\text { Emamectin } \\
\text { benzoate+Eforia }\end{array}$ & $\mathrm{LC}_{10}+\mathrm{LC}_{10}$ & 25 & 22.56 & 0.26 & 0.05 & 180 & additive \\
\hline $\begin{array}{c}\text { Emamectin } \\
\text { benzoate+Hexaflumuron }\end{array}$ & $\begin{array}{l}\mathrm{LC}_{10}+100 \\
\mathrm{mg} \mathrm{l}^{-1}\end{array}$ & 8 & 19.04 & 6.4 & 0.05 & 180 & antagonistic \\
\hline $\begin{array}{c}\text { Emamectin } \\
\text { benzoate+Acetamiprid }\end{array}$ & $\mathrm{LC}_{15}+\mathrm{LC}_{15}$ & 35 & 26.05 & 3.07 & 0.05 & 180 & additive \\
\hline $\begin{array}{c}\text { Emamectin } \\
\text { benzoate+Eforia }\end{array}$ & $\mathrm{LC}_{15}+\mathrm{LC}_{15}$ & 32 & 29.45 & 0.22 & 0.05 & 180 & additive \\
\hline $\begin{array}{l}\text { Emamectin } \\
\text { benzoate+Hexaflumuron }\end{array}$ & $\begin{array}{l}\mathrm{LC}_{15}+100 \\
\mathrm{mg} \mathrm{l}^{-1}\end{array}$ & 10 & 26.05 & 9.88 & 0.05 & 180 & antagonistic \\
\hline $\begin{array}{c}\text { Emamectin } \\
\text { benzoate+Acetamiprid }\end{array}$ & $\mathrm{LC}_{25}+\mathrm{LC}_{25}$ & 58 & 45.25 & 3.59 & 0.05 & 180 & additive \\
\hline $\begin{array}{c}\text { Emamectin } \\
\text { benzoate+Eforia }\end{array}$ & $\mathrm{LC}_{25}+\mathrm{LC}_{25}$ & 53 & 46.71 & 0.84 & 0.05 & 180 & additive \\
\hline $\begin{array}{l}\text { Emamectin } \\
\text { benzoate+Hexaflumuron }\end{array}$ & $\begin{array}{l}\mathrm{LC}_{25}+100 \\
\mathrm{mg} \mathrm{l}^{-1}\end{array}$ & 12 & 32.84 & 13.22 & 0.05 & 180 & antagonistic \\
\hline $\begin{array}{c}\text { Emamectin } \\
\text { benzoate+Acetamiprid }\end{array}$ & $\mathrm{LC}_{50}+\mathrm{LC}_{50}$ & 95 & 75.56 & 5 & 0.05 & 180 & synergistic \\
\hline $\begin{array}{c}\text { Emamectin } \\
\text { benzoate+Eforia }\end{array}$ & $\mathrm{LC}_{50}+\mathrm{LC}_{50}$ & 78 & 76.6 & 0.02 & 0.05 & 180 & additive \\
\hline $\begin{array}{c}\text { Emamectin } \\
\text { benzoate+Hexaflumuron }\end{array}$ & $\begin{array}{c}\mathrm{LC}_{50}+100 \\
\mathrm{mg} \mathrm{l}^{-1}\end{array}$ & 10 & 52.16 & 34.07 & 0.05 & 180 & antagonistic \\
\hline
\end{tabular}

a The expected mortality of combination

$\mathrm{b}$ Total number of insects exposed

c The type of interaction (synergistic, additive or antagonistic) was determined by comparing the expected and observed mortalities as described by Koppenhofer and Kaya (1996).

\section{General esterase activity}

The data obtained for $\alpha$-eterase assay $\left(\mathrm{F}=24.207 ; \mathrm{df}_{\mathrm{t}, \mathrm{e}}=4,10 ; \mathrm{P}<0.05\right)$ showed the highest activity when emamectin benzoate mixed with either acetamiprid $(0.496 \mu \mathrm{mol} / \mathrm{min} / \mathrm{mg}$ protein $)$ or eforia $\left(0.442 \mu \mathrm{mol} / \mathrm{min} / \mathrm{mg}\right.$ protein) at $\mathrm{LC}_{15}: \mathrm{LC}_{15}$ ratio as compared with emamectin benzoate alone $(0.234 \mu \mathrm{mol} / \mathrm{min} / \mathrm{mg}$ protein) or control $(0.19 \mu \mathrm{mol} / \mathrm{min} / \mathrm{mg}$ protein $)$. The activities obtained for $\beta$ - 
esterase $\left(\mathrm{F}=0.87 ; \mathrm{df}_{\mathrm{t}, \mathrm{e}}=4,10 ; \mathrm{P}>0.05\right)$ showed no significant differences among the combinations, emamectin benzoate alone and control (Figure 1).

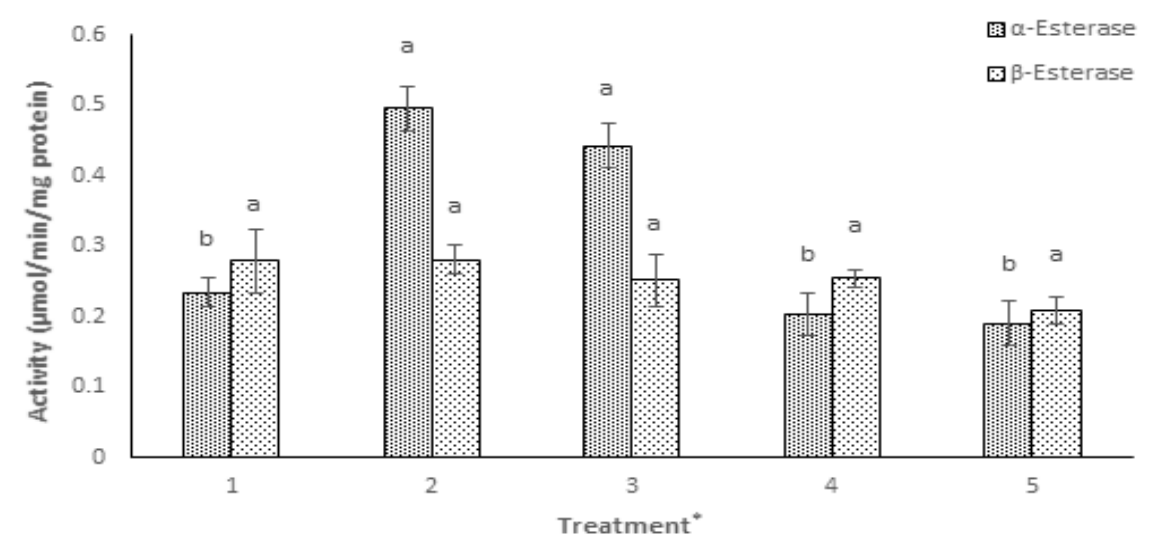

Figure 1. The effects of insecticides mixture on $\alpha$ - and $\beta$ - esterase activity (mean $\pm \mathrm{SE}$ ) in $2^{\text {nd }}$ instar larvae of Tuta absoluta

Different letters indicate that the specifc activities of the enzymes are signifcantly different from each other by LSD test $(\mathrm{P}<0.05)$

* Emamectin benzoate alone (1), mixtures of emamectin benzoate with: acetamiprid (2), eforia (3), hexaflumuron (4) and control (5)

\section{Total protein content}

The data in Figure 2 shows that protein content in larvae treated with emamectin benzoate mixed with either acetamiprid $(0.845 \mu \mathrm{g} / \mathrm{mg})$ or eforia $(0.744 \mu \mathrm{g} / \mathrm{mg})$ at $\mathrm{LC}_{15}: \mathrm{LC}_{15}$ ratio and hexaflumuron $(0.925 \mu \mathrm{g} / \mathrm{mg})$ at $\mathrm{LC}_{15}: 100 \mathrm{mg} \mathrm{L}^{-1}$ ratio significantly reduced as compared with emamectin benzoate alone $(1.66 \mu \mathrm{g} / \mathrm{mg})$ or control $(1.732 \mu \mathrm{g} / \mathrm{mg})\left(\mathrm{F}=19.607 ; \mathrm{df}_{\mathrm{t}, \mathrm{e}}=4\right.$, 10; $\mathrm{P}<0.05)$.

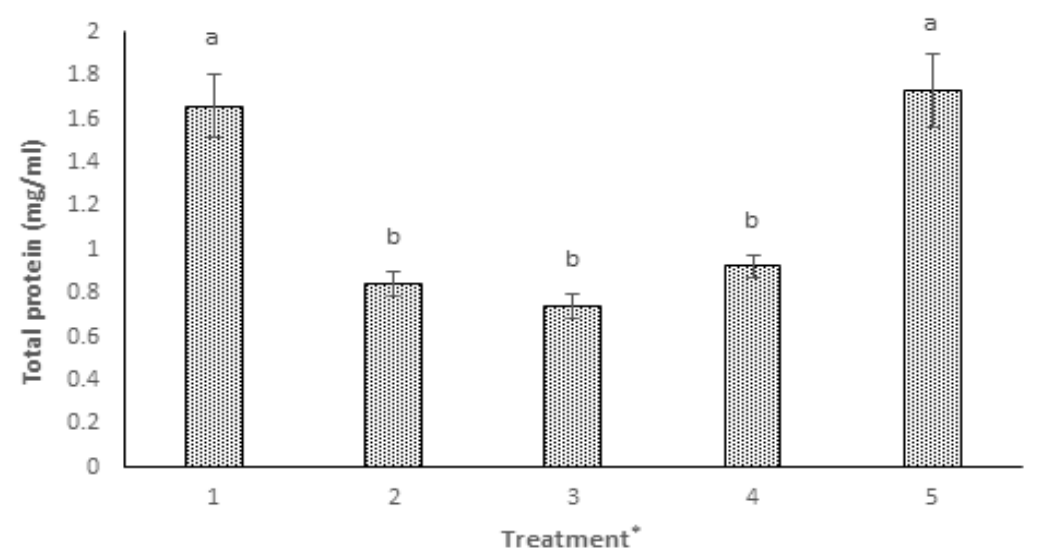

Figure 2. The effects of interaction of emamectin benzoate with other insecticides on the total protein content (mean \pm SE) of $2^{\text {nd }}$ instar larvae of Tuta absoluta

Different letters indicate that the protein contents are signifcantly different from each other by LSD test $(\mathrm{P}<0.05)$

* Emamectin benzoate alone (1), mixtures of emamectin benzoate with: acetamiprid (2), eforia (3), hexaflumuron (4) and control (5) 


\section{Discussion}

Based on the results of this study, the emamectin benzoate showed the best efficacy against $2^{\text {nd }}$ instar larvae of T. absoluta. Many researchers reported the efficacy of emamectin benzoate on different insect pests like T. absoluta (Gacemi and Guenaoui, 2012) and Helicoverpa zea Boddie (Lepidoptera: Noctuidae) (López et al., 2010). Moreover, (Mahmoud et al., 2013) showed a remarkable reduction in the population of $T$. absoluta and Helicoverpa armigera (Hübner) (Lepidoptera: Noctuidae) treated by emamectin benzoate. Acetamiprid was the second most effective insecticide against T. absoluta, in this study, similar to (Nozad et al., 2017) findings. However, (Yankova and Ganeva, 2013) reported that acetamiprid had inadequate effectiveness towards T. absoluta. (AL-Kherb, 2011) noted that acetamiprid could be considered promising candidates in controlling Bemicia tabaci (Homoptera: Aleyrodidae) with a lower value of harmful effect on beneficial insect species. Eforia was another effective insecticide in our study. The results of Duchovskiene (2016) indicated that eforia was a suitable insecticide to reduce abundance of the most harmful Lepidopteran pests in white cabbage.

Combination of emamectin benzoate with acetamiprid showed synergistic effects against $2^{\text {nd }}$ instar larvae of T. absoluta. (Mahmoud et al., 2013) noted that emamectin benzoate combined with either imidacloprid, indoxacarb, profenofos, chlorfenapyr or methomyl achieved a considerable reduction population in third instar larvae of T. absoluta. (Mahmoud et al., 2014) demonstrated that chlorantraniliprole insecticide was the most toxic against T. absoluta followed by $20 \%$ emamectinbenzoate $+60 \%$ bifenithrin and lambda-cyhalothrin. In our study, the combination of hexaflumuron with emamectin benzoate showed antagonistic interactions. It can be suggested that emamectin benzoate caused larvae to face the cessation of feeding, so hexaflumuron could not enter larvae body through the digestive tract resulting in antagonistic interaction. (Metayi et al., 2015) presented that all mixtures of emamectin benzoate (at $\mathrm{LC}_{10}$ or $\mathrm{LC}_{25}$ ) with novaluron or diflubenzuron (at $\mathrm{LC}_{10}$ or $\mathrm{LC}_{25}$ ) resulted in antagonistic effects.

The emamectin benzoate can affect the nervous system of arthropods by increasing chloride ion flux at the neuromuscular junction, resulting in cessation of feeding and irreversible paralysis (Ishaaya, 2001). By inhibiting the nicotinic acetylcholine receptor (nAChR), neonicotinoids such as acetamiprid disrupt the insect's nervous system by prolonged activation of the receptors as they are not hydrolyzed by acetylcholinesterase, leading to the death of the insects (Belzunces et al., 2012). Accordingly, the mixture of these insecticides with different modes of action supplements the action of anotherone for $\mathrm{T}$. absoluta control. Also, Corbett (1974) has a general theory to explain the synergistic interactions among insecticides. According to his theory, one toxicant in the mixture synergizes the toxicity of the other one by participating in the metabolic detoxification of it. Moreover, in our study, when the combination of emamectin benzoate with other insecticides was applied, they might bind to detoxifying enzymes and then prevent the binding and subsequent degradation of emamectin benzoate by these enzymes, so enhanced the toxicity of this insecticide. Formerly, it has been supposed that OPs in combination with pyrethroids, inhibit the detoxifying enzymes such as monooxygenases and esterases in different insect pests (Bryne and Devonshire, 1991; Martin et al., 2003).

The results regarding esterase enzyme activity and protein content of $2^{\text {nd }}$ instar larvae, support the observed toxicity ratios of the combinations. Esterases, as important detoxifying enzymes, hydrolyze the esteric bond in synthetic chemicals (Hemingway and 
Karunatne, 1998). In the present study, the activity of $\alpha$-esterase increased when larvae were treated with a mixture of emamectin benzoate with either acetamiprid or eforia. This shows that $\alpha$-esterase enzyme has an important role in detoxification of these mixtures, suggesting a high toxicity of the mixtures of tested insecticides to T. absoluta. The biochemical analysis of carboxylesterase and GST by (Badawy et al., 2014) showed that these enzymes detoxified the low doses of acetamiprid and pymetrozine in Apis mellifera $\mathrm{L}$. (Hymenoptera:Apidae). According to (Abdel-Mageed and Shalaby, 2011), thiamethoxam + lambda-cyhalothrin $\left(\right.$ Engeo $^{\mathrm{R}}$ ) caused a significant increase in acetylcholinesterase activity of S. littoralis. The role of esterases in resistance of Brazilian populations of T. absoluta against abamectin is reported by (Siqueira et al., 2001). (Zibaee et al., 2016) showed that the exposure of $4^{\text {th }}$ instar larvae of T. absoluta to chlorpyrifos increased the esterases activity after 24 and $48 \mathrm{~h}$. Esterase and MFO are two enzymes responsible for reducing toxicity of spinosad in T. absoluta (Reyes et al., 2012).

In this study, the amount of total protein of larvae decreased by mixture of emamectin benzoate with either acetamiprid, eforia or hexaflumuron, suggesting that these mixtures have high toxicity against T. absoluta. This might be due to the dissociation of protein into amino acids, that with the entry of these amino acids to TCA cycle, they will aid to store energy for the insect (Nath et al., 1997). Furthermore, (Nath et al., 1997) noted that sublethal concentrations of fenitrothion and ethion caused depletion in total protein content of $5^{\text {th }}$ instar Bombyx mori (L.) (Lepidoptera: Bombycidae) larvae that was followed by an addition in free amino acids. The reduction in protein content induced by emamectin benzoate + hexaflumuron in our study was similar to the finding of (Assar et al., 2016), who stated that total protein and lipid contents of S. littoralis larvae decreased with emamectin, hexaflumuron and teflubenzuron. (Wilde et al., 2016) reported that the level of protein in tissue extracts of A. mellifera significantly reduced from the $1^{\text {st }}$ to the $2^{\text {nd }}$ instars treated with imidacloprid. According to (Manal and Abdel-Mageed, 2018), the total protein content of M. domestica adults treated with tested mixtures such as deltamethrin+abamectin, lambada-cyhalothrin+khaya extract, indoxacarb+pomegranate, chlorantraniliprole+jojoba oil and methomyl+jojoba oil reduced compared with control.

Several studies showed that populations of T. absoluta might have multiple insecticide resistance (Siqueira et al., 2000; Siqueira et al., 2001; Guedes and Siqueira, 2012). Pesticides mixtures with different modes of action might postpone the resistance development of pest population (Bielza et al., 2009). Therefore, it can manage pesticide resistance and control a broad spectrum of pest species. Moreover, the expenses of excessive use of insecticides and the risks of environmental pollution could be reduced. Therefore, it can be used as a component of integrated pest management programs in case of synergistic and additive interactions. In this study, the mixtures of emamectin benzoatewith acetamiprid and eforia are good options for managing T. absoluta.

\section{Conclusions}

Generally, the mixtures of acetamiprid and eforia with emamectin benzoate showed higher negative impacts against $2^{\text {nd }}$ instar larvae than emamectin benzoate alone. Therefore, it can manage insecticide resistance and reduce damage of T. absoluta. 


\section{Acknowledgements}

This work was fnancially supported by the University of Mohaghegh Ardabili (Ardabil, Iran), which is appreciated.

\section{References}

Abbas, N, Crickmore, N, Shad, SA. (2015). Efficacy of insecticide mixtures against a resistant strain of housefly (Diptera: Muscidae) collected from a poultry farm. Int. J. Trop. Insect Sci., 35:48-53.

Abbott, WS. (1925). A method of computing the effectiveness of an insecticide. J. Econom. Entomol., 18:265-267.

Abdel-Mageed, AEM, Shalaby, SEM. (2011). Toxicity and biochemical impacts of some new insecticide mixtures on cotton leafworm Spodoptera littoralis (Boisd.). Plant Protect. Sci., 47(4):166-175.

All, JN, Ali, M, Hornyak, EP, Weaver, JB. (1977). Joint action of two pyrethroids with methylparathion, methomyl, and chlorpyrifos on Heliothiszea and $\mathrm{H}$. virescens in the laboratory and in cotton and sweetcorn. J. Econom. Entomol., 70:813-817.

AL-Kherb, (2011). Field efficacy of some neonicotinoid Insecticides on whitefly Bemiciatabaci (Homoptera: Aleyrodidae) and its natural enemies in cucumber and tomato plants in Al-qassim region, KSA. J. Entomol., 8(5):429-439.

Asher, KRS, Eliyahu, M, Ishaaya, I, Zur, M, Ben-Moshe, E. (1986). Synergism of pyrethroidorganophosphorus insecticide mixtures in insects and their toxicity against Spodoptera littoralis larvae. Phytoparasitica, 14:101-110.

Assar, AA, Abo El-Mahasen, MM, Dahi, HF, Amin, HS. (2016). Biochemical effects of some insect growth regulators and bioinsecticides against cotton leafworm, Spodoptera littoralis (Boisd.)(Lepidoptera: Noctuidae). J. Biosci. Appl. Res., 2(8):587-594.

Badawy, MEI, Nasr, HM, Rabea, EI. (2015). Toxicity and biochemical changes in the honey bee Apis mellifera exposed to four insecticides under laboratory conditions. Apidologie, 46:177-193.

Belzunces, L, Tchamitchian, S, Brunet, JL. (2012). Neural effects of insecticides in the honey bee. Apidologie, 43:348-370.

Bielza, P, Fernández, E, Graválos, C, Albellán, J. (2009). Carbamates synergize the toxicity of acrinathrin in resistant western flower thrips (Thysanoptera: Thripidae). J. Econom. Entomol, 102:393-397.

Bradford, MM. (1976). A rapid and sensitive method for the quantitation of microgram quantities of protein utilizing the principle of protein dye binding. Anal. Biochem., 72:248-254.

Braham, M, Hajji, L. (2011).Management of Tuta absoluta (Lepidoptera, Gelechiidae) with Insecticides on Tomatoes. Insecticides- Pest Engineering, 333-354. 
Bryne, FJ, Devonshire, AL. (1991). In vivo inhibition of esterase and acetylcholinesterase activities by profenofos treatment in the tobacco whitefly Bemisia tabaci (Genn) implications for routine biochemical monitoring of these enzymes. Pest. Biochem. Physiol., 40:198-204.

Campos, MR, Rodrigues, ARS, Silva, WM, Silva, TBM, Silva, VRF, Guedes, RNC, Siqueira, HAA. (2014). Spinosad and the tomato borer Tuta absoluta: A bioinsecticide, an invasive pest threat, and high insecticide resistance. PLOS ONE, 9:e103235.

Corbett, JR. (1974). The Biochemical Mode of Action of Pesticides. New York: Academic Press.

Desneux, N, Wajnberg, E, Wyskhuys, KAG, Burgio, G, Arpaia, S, NarváezVazquez, CA, GonzalezCabrera, J, Catalán Ruescas, D, Tabone, E, Frandon, J, Pizzol, J, Poncet, C, Cabello, T, Urbaneja, A (2010). Biological invasion of European tomato crops by Tuta absoluta: ecology, geographic expansion and prospects for biological control.J. Pest Sci., 83:197-215.

Duchovskienè, L. (2016). The efficancy of different insecticides for control of Lepidopteran pests on cabbage in Lithuania. Sodin. stëir Daržinink., 35(3/4):65-75.

EPPO, (2005). Data sheets on quarantine pests: Tuta absoluta: 2005 OEPP/EPPO, European and Mediterranean Plant Protection Organization. Bulletin OEPP/ EPPO, 35:434-435.

Gacemi, A, Guenaoui, Y. (2012). Efficacy of emamectin benzoate on Tuta absoluta Meyrick (Lepidoptera: Gelechiidae) infesting a protected tomato crop in Algeria. Academic J. Entomol., 5(1):37-40.

Galdino, TVS, Picanço, MC, Morais, EGF, Silva, NR, Silva, GAR, Lopes, MC. (2011). Bioassay method for toxicity studies of insecticide formulations to Tuta absoluta (MEYRICK, 1917). Sci. Agrotechnol., 35(5):869-877.

Gamil, WE, Mariy, FM, Youssef, LA, Abdel Halim, SM. (2011). Effect of indoxacarb on some biological and biochemical aspects of Spodoptera littoralis (Boisd.) larvae. Ann. Agricul. Sci., 56(2):121-126.

Ghoneim, YF, Singab, M, Abou-Yousef, HM, Abd-El-Hai, NS. (2012). Efficacy of certain insecticides and their mixtures with the tested IGRs against a field strain of the cotton leaf worm, Spodoptera littoralis (Boisd.) under laboratory conditions. Austral. J. Basic Appl. Sci., 6(6):300-304.

Guedes, RNC, Siqueira, HAA. (2012). The tomato borer Tuta absoluta: insecticide resistance and control failure. CAB Rev., 7 (055). (CAB Reviews Perspectives in Agriculture Veterinary Science Nutrition and Natural Resources 7(055):1)

Hemingway, J, Karunatne, SHP. (1998). Mosquito carboxylesterases: A review of the molecularbiology and biochemistry of a major insecticide resistance mechanism. Med. Veter. Entomol., 12:1-12.

Ishaaya, I. (2001). Biochemical processes related to insecticide action: An overview. In: Ishaaya, I., Eds. Biochemical sites of insecticides action and resistance. Berlin: Springer, pp. 1-16. 
Ishaaya, I, Mendelson, Z, Ascher, KRS, Casida, JE. (1985). Mixtures of synthetic pyrethroids and organophosphorus compounds for controlling the whitefly, Bemisia tabaci, Phytoparasitica, 13:76-77.

Khan, HAA, Akram, W, Shad, SA, Lee, JJ. (2013). Insecticide mixtures could enhance the toxicity of insecticides in a resistant dairy population of Musca domestica L. PLOS ONE, 8(4):e60929.

Koppenhofer, AM, Kaya, HK. (1996). Additive and synergistic interaction between entomopathogenic nematodes and Bacillus thuringiensis for scarab grub control. Biol. Control, 8:131-137.

López, JD, Latheef, MA, Hoffman, WC. (2010). Effect of emamectin benzoate on mortality, proboscis extension, gustation and reproduction of the corn earworm Helicoverpa zea. J. Insect Sci., 10:89. available online: insectscience.org/10.89.

Mahmoud, MM, Soliman, ASH, Abdel-Moniem, B, Abdel-Raheem, MA. (2013). Impact of some insecticides and their mixtures on the population of tomato borers, Tuta absoluta (Meyrick) (Lepidoptera: Gelechiidae) and Helicoverpa armigera (Hübner) (Lepidoptera: Noctuidae) intomato crop at Upper Egypt. Arch. Phytopathol. Plant Protect., 47(14). http://dx.doi.org/10.1080/03235408.2013.857226

Mahmoud, MM, Soliman, ASH, Abdel-Moniem, B, Abdel-Raheem, MA. (2014). Effect of certain low toxicity insecticides against tomato leaf miner, Tuta absoluta (Lepidoptera: Gelechiidae) with reference to their residues in harvested tomato fruits. Int.J.Agricul. Res., 9(4 ):210-218.

Manal, AR, Abdel-Mageed, AR. (2018). Toxicity of traditional, novel and bio-insecticides and theirmixtures against house fly Musca domestica in relation to somebiochemical activities. Res. J. Environ. Toxicol., 12(1):1-10.

Martin, T, Ochou, OG, Vaissayre, M, Fournier, D. (2003). Organophosphorus insecticides synergisepyrethroids in the resistant strain of cotton bollworm, Helicoverpa armigera (Lepidoptera: Noctuidae) from West Africa. J. Econ. Entomol., 92:468-474.

Metayi, MHA, Ibrahiem, MAM, El-Deeb, DA. (2015). Toxicity and Some Biological Effects of Emamectin Benzoate, Novaluron and Diflubenzuron against Cotton Leafworm. Alex. Sci. Exchange J., 36(4):350-357.

Nath, BS, Suresh, ., Varma, BM, Kumar, RPS. (1997). Bombyx mori (Lepidoptera: Bombycidae) in response to organophosphorus insecticides toxicity. Ecotoxicol. Environ. Safety, 36(2):169-173.

Nozad-Bonab, Z, Hejazi, MJ, Iranipour, S, Arzanlou, M. (2017). Lethal and sublethal effects of some chemicaland biological insecticides on Tuta absoluta (Lepidoptera: Gelechiidae) eggs and neonates. J. Econ. Entomol., 110(3):1138-1144.

Reyes, M, Rocha, K, Alarcón, L, Siegwart , M, Sauphanor, B. (2012). Metabolic mechanisms involved in the resistance of field populations of Tuta absoluta (Meyrick) (Lepidoptera: Gelechiidae) to spinosad. Pest. Biochem. Physiol., 102:45-50. 
Reyes, M, Franck, P, Charmillot, PJ, Ioriatti, C, Olivares, J, Pasqualini, E, Sauphanor, B. (2007). Diversity of insecticide resistance mechanisms and spectrum in European populations of the codling moth, Cydia pomonella. Pest Manag. Sci., 63:890-902.

Roditakis, E, Skarmoutsou, C, Staurakaki, M. (2013). Toxicity of insecticides to populations of tomato borer Tuta absoluta (Meyrick) from Greece. Pest Manag. Sci., 69:834-840.

Saddiq, B, Ejaz, M, Shad, SA, Aslam, M. (2017). Assessing the combined toxicity of conventional and newer insecticides on the cotton mealybug Phenacoccus solenopsis. Ecotoxicology, 26:12401249.

Siqueira, HAA, Guedes, RNC, Picanco, MC. (2000). Cartap resistance and synergism in populations of Tuta absoluta (Lep.,Gelechiidae). J. Appl. Entomol., 124:233-238.

Siqueira, HAA, Guedes, RNC, Fragoso, DB, Magalhaes, LC. (2001). Abamectin resistance and synergism in Brazilian populations of Tuta absoluta (Meyrick) (Lepidoptera: Gelechiidae). Int.J. Pest Manag., 47:247-251.

Sun, YP. (1950). Toxicity index-An improved method of comparing the relative toxicity of insecticides. J. Econ. Entomol., 43:45-53.

Torres, JB, Faria, C, Evangelista, WSJ, Pratissoli, D. (2001).Within-plantdistribution of the leaf miner Tuta absoluta (Meyrick) immatures in processing tomatoes, with notes on plant phenology. Int.J. Pest Manag., 47(3):173-178.

vanAsperen, K. (1962). Study of housefly esterases by means of sensitive colorimetric method. J. Insect Physiol., 8:401-416.

Vanhaelen, N, Haubruge, E, Lognay, G, Francis, F. (2001). Housefly glutathione S-transferase and effect of Brassicaceae secondary metabolites. Pest. Biochem. Physiol., 71:170-177.

Wakil, W, Ashfaq, M, Ghazanfar, MU. (2009). Integrated management of Helicoverpa armigera in chickpea in rainfed areas of Punjab, Pakistan. Phytoparasitica, 37:415-420.

Wilde, J., Fraczek, R. J., Siudaa, M., Bak, B., Hatjina, F. and Miszczak, A. (2016). The influence of sublethal doses of imidacloprid on protein content and proteolytic activity in honey bees (Apis mellifera L.). Journal of Apicultural Research, 55(2): 212-220.

Wing, KD, Sacher, M, Kagaya, Y, Tsurubuchi, Y, Mulderig, L, Connair, M, Schnee, M. (2000). Bioactivation and mode of action of the oxadiazineindoxacarb in insects. Crop Protect., 19:537545.

Wolfenbarger, DA, Cantu, E. (1975). Enhanced toxicity of carbaryl when combined with synergists against larvae of the bollworm, Heliothis zea and the tobacco budworm, Heliothis virescens. Flor. Entomol., 58:103-104.

Yankova, V, Ganeva, D. (2013). Possibilities for control of tomato leaf miner Tuta absoluta (Meyrick) by application of insecticides in tomato greenhouse growing. Bulgar. J. Agricul. Sci., 19(4):728-731 
Zibaee, I, Bandani, AR, Sabahi, GH. (2016). The expression profile of detoxifying enzyme of tomato leaf miner,Tuta absoluta Meyrik (Lepidoptera: Gelechiidae) to chlorpyrifos. Arthropods, 5(2):77-86.

How to cite this article: Mohsen Taleh, Hooshang Rafiee Dastjerdi, Bahram Naseri, Aziz Sheikhi Garjan, Khalil Talebi Jahromi, Effects of Emamectin Benzoate Combined with Acetamiprid, Eforia and Hexaflumuron Against Tuta Absoluta (Lep.: Gelechiidae). International Journal of Advanced Biological and Biomedical Research, 2020, 8(2), 180-192. Link: http://www.ijabbr.com/article 37168.html 